УДК 541.1

ББК 24.5

\title{
OZONE DECOMPOSITION ON THE SURFACE OF METAL OXIDE CATALYST
}

\author{
Batakliev Todor Todorov
}

$\mathrm{PhD}$ in Chemistry, Assistant Professor, Institute of Catalysis,

Bulgarian Academy of Sciences

todor@ic.bas.bg

Akademika Boncheva St., 11, 1113 Sofia, Bulgaria

\section{Georgiev Vladimir Ferdinandov}

$\mathrm{PhD}$ in Chemistry, Assistant Professor,

Institute of Catalysis, Bulgarian Academy of Sciences

vlado@ic.bas.bg

Akademika Boncheva St., 11, 1113 Sofia, Bulgaria

Anachkov Metodi Parvanov

$\mathrm{PhD}$ in Chemistry, Associate Professor,

Institute of Catalysis, Bulgarian Academy of Sciences

anachkov@ic.bas.bg

Akademika Boncheva St., 11, 1113 Sofia, Bulgaria

\section{Rakovsky Slavcho Kirilov}

Doctor of Chemical Sciences, Professor,

Institute of Catalysis, Bulgarian Academy of Sciences

rakovsky@ic.bas.bg

Akademika Boncheva St., 11, 1113 Sofia, Bulgaria

\section{Zaikov Gennadiy Efremovich}

Doctor of Chemical Sciences, Professor,

Head of Department of Biological and Chemical Physics of Polymers, Institute of Biochemical Physics named after N.M. Emanuel, RAS

chembio@sky.chph.ras.ru

Kosygina St., 4, 119334 Moscow, Russian Federation

Abstract. The catalytic decomposition of ozone to molecular oxygen over catalytic mixture containing manganese, copper and nickel oxides was investigated in the present work. The catalytic activity was evaluated on the basis of the decomposition coefficient $\gamma$ 
which is proportional to ozone decomposition rate, and it has been already used in other studies for catalytic activity estimation. The reaction was studied in the presence of thermally modified catalytic samples operating at different temperatures and ozone flow rates. The catalyst changes were followed by kinetic methods, surface measurements, temperature programmed reduction and IR-spectroscopy. The phase composition of the metal oxide catalyst was determined by X-ray diffraction. The catalyst mixture has shown high activity in ozone decomposition at wet and dry $\mathrm{O}_{3} / \mathrm{O}_{2}$ gas mixtures. The mechanism of catalytic ozone degradation was suggested.

Key words: ozone, catalyst, decomposition, synthesis, kinetics, mechanism.

\section{Introduction}

Ozone finds wide application in such important industrial processes like: purification of drinking water, bleaching of textiles, oxidation of sulfurous gas, complete oxidation of exhaust gases from production of nitric acid and production of many organic compounds [21]. Ozone in the atmosphere protects the Earth's surface against UV radiation, but on the ground level it is an air contaminant $[7 ; 20 ; 21]$. At this level ozone can be removed by adsorption, absorption, thermal and catalytic decomposition. The most effective catalysts for ozone decomposition are based on manganese oxide $[10 ; 12 ; 18 ; 19]$. The main method for purification of waste gases containing residual ozone is the heterogeneous catalytic decomposition. Noble metals like $\mathrm{Pt}, \mathrm{Ag}, \mathrm{Pd}$ and transition metal oxides including $\mathrm{Co}, \mathrm{Cu}$, and $\mathrm{Ni}$ supported on $\gamma-\mathrm{Al}_{2} \mathrm{O}_{3}, \mathrm{SiO}_{2}$ and $\mathrm{TiO}_{2}$ also are effective catalysts in this reaction $[3 ; 4 ; 9 ; 11$; $16 ; 24 ; 26]$, as it can be mentioned for activated carbon fibers [25].

The decomposition of ozone is a thermodynamically favored process with a heat of reaction of $\Delta \mathrm{H}^{0}{ }_{298}=-138 \mathrm{~kJ} / \mathrm{mol}$ and free energy of reaction of $\Delta \mathrm{G}^{0}{ }_{298}=-163 \mathrm{~kJ} / \mathrm{mol}$ [17]. The ozone structure is resonance stabilized that is a reason for its relative stability. The coefficient of ozone decomposition $\gamma$ was used in other studies for investigation of $\mathrm{NiO}$ addition influence over cement-containing catalysts activity [15] and for study of thermal treatment influence over oxide catalyst activity [27].

The aim of present study is to apply mixed metal oxide catalyst for ozone decomposition, to investigate its behavior at different conditions and to determine its composition and surface properties using different physical methods for analysis.

\section{Experimental}

The basic copper, manganese, nickel carbonates and clay-bearing cement are milled in advance, then carefully mixed, crushed and compressed under pressure $4 \mathrm{t} / \mathrm{cm}^{2}$. The resulting tablets were treated hydrothermally at temperature of $80^{\circ} \mathrm{C}$ for 6 hours, dried at $120^{\circ} \mathrm{C}$ for 6 hours and calcinated at $420^{\circ} \mathrm{C}$ for 6 hours. The metal oxide catalyst based on the mixture of manganese oxide (20 wt \%), copper oxide (10 wt \%), nickel oxide (30 wt \%) and claybearing cement (40 wt \%) was thermally modified at $500{ }^{\circ} \mathrm{C}$ for $2 \mathrm{~h}$ and finally was applied in our investigation as catalyst for ozone decomposition in dry and water enriched gas flows. The catalyst was granulated and contained cylindrical grains with a diameter of about $5 \mathrm{~mm}$ and thickness of $3 \mathrm{~mm}$.

The reactor for kinetic measurements was a glass tube $(6 \times 150 \mathrm{~mm})$ filled in with $0.08-0.12 \mathrm{~g}$ of catalyst. Fig. 1 shows the schematic of the experimental set-up for all kinetics.

The kinetic measurements of ozone degradation were performed at flow rates ranging from 6.0 to $241 \mathrm{~h}^{-1}$ and ozone concentration from 1.0 to $1.2 \mathrm{mM}$. Ozone was generated by passing dry oxygen through a high-voltage silentdischarge ozone generator. At $15-20 \mathrm{kV}$ was achieved ozone concentration about $1 \mathrm{mM}$. The inlet and outlet ozone concentrations were monitored using an UV absorption-type ozone analyzer at $300 \mathrm{~nm}$.

The specific surface area of the catalyst $\left(72 \mathrm{~m}^{2} / \mathrm{g}\right)$ was measured by $\mathrm{N}_{2}$ adsorptiondesorption isotherms at $77 \mathrm{~K}$ using BET method in a FlowSorb 2300 instrument (Micromeritics Instrument Corporation). IR studies were performed in the transmittance mode using a Nicolet 6700 FT-IR spectrometer (Thermo 


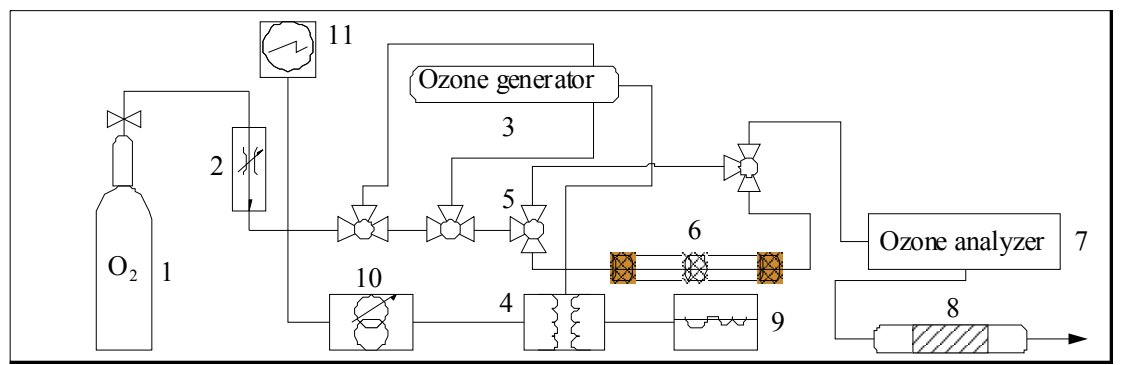

Fig. 1. Experimental set-up of reaction system for catalytic decomposition of ozone:

1 - oxygen; 2 - flow controller; 3 - ozone generator; 4 - transformer; 5 - three way turn cock; 6 -reactor charged with catalyst sample; 7 - ozone analyzer; 8 - reactor for decomposition of residual ozone; 9 - current stabilizer; 10 - autotransformer; 11 - voltmeter

Electron Corporation). A mixture of $\mathrm{KBr}$ and manganese oxide catalyst (100:1) was milled in an agate mortar manually before the preparation of pellets. The spectra were obtained by averaging 50 scans with $0.4 \mathrm{~cm}^{-1}$ resolution.

A typical TPR experiment is done by passing a $\mathrm{H}_{2}$ stream over a catalyst while it is heated linearly and monitoring the consumption of $\mathrm{H}_{2}$ with a thermal conductivity detector or mass spectrometer. In our study a $10 \% \mathrm{H}_{2} / \mathrm{Ar}$ mixture was used and the consumption of $\mathrm{H}_{2}$ was monitored using a thermal conductivity detector. A linear heating rate of $0.17 \mathrm{~K} \mathrm{~s}^{-1}$ was used for the experiment. X-ray diffraction (XRD) analysis was used to determine the crystalline metal oxide phases for the supported catalyst. A Bruker D8 Advance powder diffractometer with $\mathrm{Cu} \mathrm{K \alpha}$ radiation source and SolX detector was used. The samples were scanned from $2 \mathrm{q}$ angles of $10^{\circ}$ to $80^{\circ}$ at a rate of $0.04^{\circ} \mathrm{s}^{-1}$. The $\mathrm{X}$-ray power operated with a current of $40 \mathrm{~mA}$ and a voltage of $45 \mathrm{kV}$.

\section{Results and Discussion}

The catalytic activity was evaluated on the basis of the coefficient $g$ [14] that is proportional to ozone decomposition rate and to catalyst efficiency. It has been already used in other studies [15;27]:

$$
\gamma=\frac{4 \omega}{V_{t} S} \ln \frac{\left[\mathrm{O}_{3}\right]_{0}}{\left[\mathrm{O}_{3}\right]}
$$

where $\omega$ is the flow rate, $V_{t}$ - specific heat rate of ozone molecules, $S$ - geometrical surface of catalyst sample and $\left[\mathrm{O}_{3}\right]_{0}$ and $\left[\mathrm{O}_{3}\right]$ - inlet and outlet ozone concentrations, respectively.
In general, there is no precise estimation of $\gamma$ by solving the diffusion-kinetic equation. This is possible in some special cases, for example to find $\gamma$ using the approximate method of FrankKamenetsky (method of equally accessible surface) [5]. Equally accessible surface is that surface where in each section the molecules fall with equal probability. The rate of the chemical reaction on the surface is expressed by concentration of reacting molecules in the volume near the surface. For reactions of first order:

$$
w_{s}=k_{s} c_{s}=k c^{\prime}
$$

The parameters dimension is as follows: $w_{s}-\left(\right.$ molecules $\left./ \mathrm{cm}^{2} . s\right), \kappa_{s}$ and $\kappa-\left(s^{-1}\right)$ and $(\mathrm{cm} /$ $s), c_{s}$ и $c^{\prime}-\left(\right.$ molecules $\left./ \mathrm{cm}^{2}\right)$ и $\left(\right.$ molecules $\left./ \mathrm{cm}^{3}\right)$. It has been suggested that the molecular flow from volume to surface does not depend on the reaction rate, and with approximation it is defined of the equation:

$$
j=\beta\left(c-c^{\prime}\right)
$$

where: $\beta$ - coefficient of mass transfer, having dimension as the rate constant $\mathrm{k}$, equal to $\mathrm{cm} s^{-1}, c$ and $c^{\prime}$-concentration in the regions of the volume, where the flow is passing trough.

The distance between the surface and the region with concentration $c^{\prime}$ the ozone molecules pass without collisions with average specific heat rate $v_{T}$. The number of hits on unit of surface per unit of time $z=v_{T} c^{\prime}$ and taking into account the definition of coefficient of ozone decomposition it has been found that:

$$
\gamma=\frac{k c^{\prime}}{z}=\frac{4 k}{v_{T}} .
$$




\section{ТЕХНИКО-ТЕХНОЛОГИЧЕСКИЕ ИННОВАЦИИ}

Thus, the coefficient $\gamma$ is related to the rate constant $k$. Now we could consider the case when the surface, where the reaction takes place, is located in an unlimited volume of gas. In stationary conditions the molecular flow toward the surface is equal to the chemical reaction rate:

$$
w_{s}=\frac{\beta k c}{k+\beta}=k_{\mathrm{eff}} c
$$

where $c$ - concentration of actives molecules standing to great distance from the catalytic surface.

Thus, the rate of reaction on the surface is expressed by the concentration in the volume and the effective rate constant that depends on the rate constant $\mathrm{k}$ and the coefficient of mass transfer $\beta$. Obviously:

$$
\frac{1}{k_{\text {eff }}}=\frac{1}{k}+\frac{1}{\beta} \text {. }
$$

If $\beta>\mathrm{k}$, then $c^{\prime}=c$ and $k_{\mathrm{eff}}=k$ : the total reaction rate is limited by the no hits stage with constant $k$. In this case the reaction proceeds in the kinetic region. If $\beta<<k, c^{\prime}<<c$ and $k_{\text {eff }}=\beta$ the reaction rate is determined by the rate of mass transfer and the reaction occurs in the diffusion region.

On the other hand [14], when operating in stationary conditions the relationship between the constant rate of the reaction of heterogeneous ozone decomposition and the coefficient of ozone decomposition $\gamma$ is given by the formula:

$$
\gamma=\frac{4 k_{\text {het }} V}{S v_{T}}
$$

where: $V$ - volume of reactor, $S$-geometric surface of catalyst, $v_{T}$-specific heat rate of ozone molecules.

Taking into account the dependence of the gas flow rate from the reactor radius, and considering the concentration of active ozone molecules and the reaction time of ozone decomposition, after complex mathematical transformations the latter formula passes into the expression:

$$
\gamma=\frac{4 \omega}{S v_{T}} \ln \frac{\left[\mathrm{O}_{3}\right]_{0}}{\left[\mathrm{O}_{3}\right]}
$$

where: $\omega$-gas flow rate, $\left[\mathrm{O}_{3}\right]_{0}$ и $\left[\mathrm{O}_{3}\right]$-inlet and outlet ozone concentrations.

This formula is applicable for tubular type reactor, when the catalyst is supported as thin layer on the walls in the inner side of the tube. The expression is also convenient for calculation of catalytic activity in the case when the reactor is filled with granulated catalytic samples having specific geometric surface. Therefore, this method has been used by us for calculation of the catalysts activity in the process of ozone decomposition.

\section{Results and Discussion}

Fig. 2 shows changing catalytic activity of the cement containing catalyst when the calcination temperature of the samples is different. All the experiments were made in dry conditions and ozone flow rate of $61 \mathrm{~h}^{-1}$. The $\mathrm{MnO}_{\mathrm{x}} / \mathrm{CuO} / \mathrm{NiO}$ catalyst has catalytic activity in ozone decomposition that

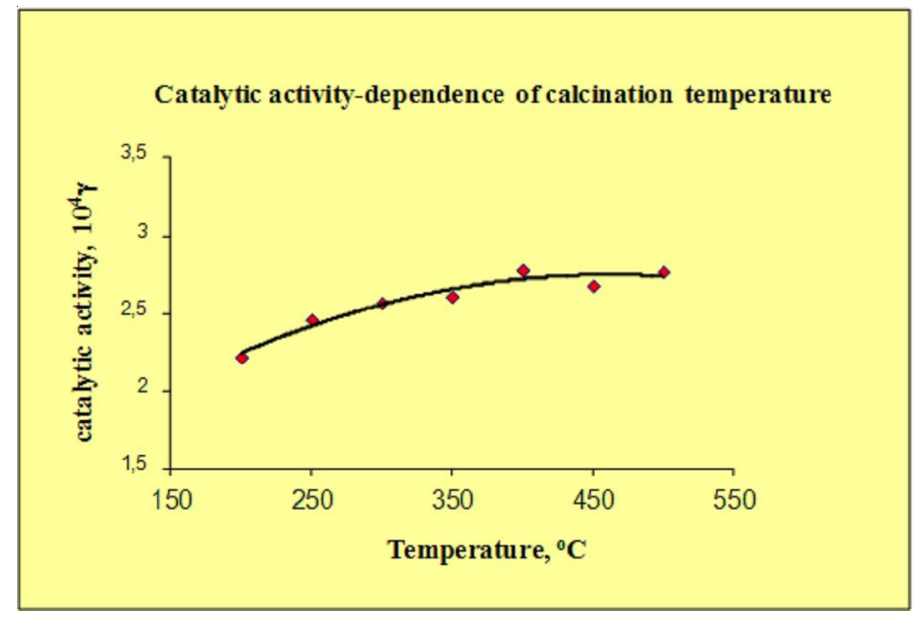

Fig. 2. Dependence of the catalytic activity in ozone decomposition on calcination temperature 
does not change dramatically with calcination temperatures increasing. However, we can see that the catalyst is more active when the calcination temperature is in the range of $400-500{ }^{\circ} \mathrm{C}$. On Fig. 3 the changes of $\gamma$ at two different flow rates in temperature range of 258-323 $\mathrm{K}$ are shown. The calculated activation energy is $5 \mathrm{~kJ} / \mathrm{mol}$. In these experiments the reactor was kept up at constant temperature enough time to get the necessary value. The duration of the decomposition reaction and the reaction time were much smaller than the time of cooling or heating the reactor. That means that the temperature inside the reactor was maintained constant during the measurement of ozone decomposition rate. The difference between the values of $\gamma$ at different flow rates is due to the low loading of catalyst. The low values of $\mathrm{E}_{\mathrm{a}}$ are directly connected with the fact that limited stage of reaction is the adsorption of ozone on catalytic surface.

On Fig. 4 are presented the changes of $\gamma$ depending on temperature and humidity of the gas flow. The measured activation energy was also $5 \mathrm{~kJ} / \mathrm{mol}$. It was found out that the humidity of the gas flow decreases the catalytic activity by $10 \%$, but the catalyst does not disturb its stability in the time of ozonation.

Fig. 5 presents the changes of $\gamma$ at different flow rates at two temperatures -258 and $298 \mathrm{~K}$. It can be seen that $\gamma$ is proportional to the flow rate at both temperatures. The coefficient of

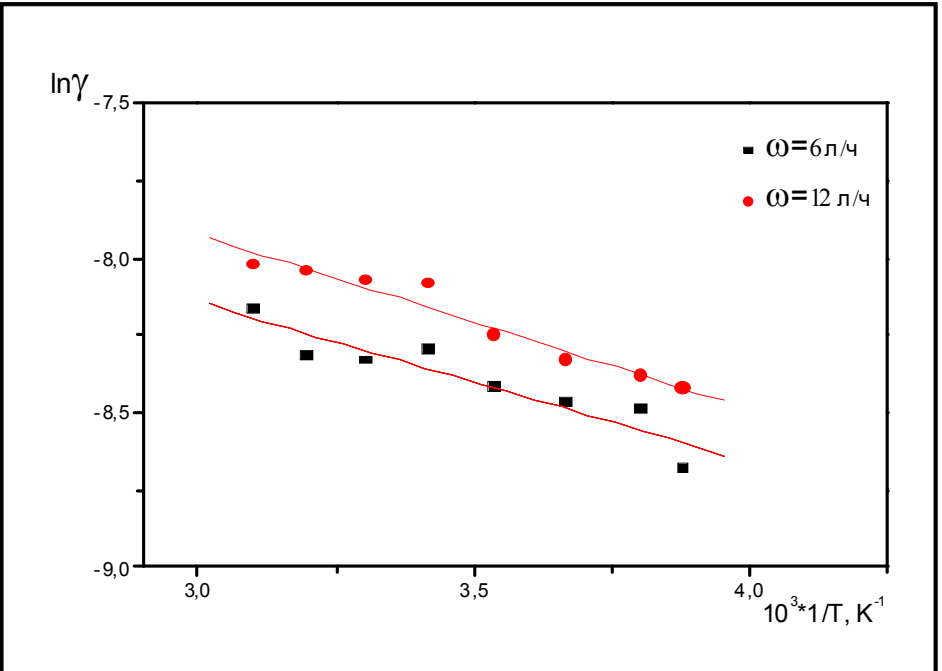

Fig. 3. Dependence of the catalytic activity in ozone decomposition on reaction temperature at two different flow rates

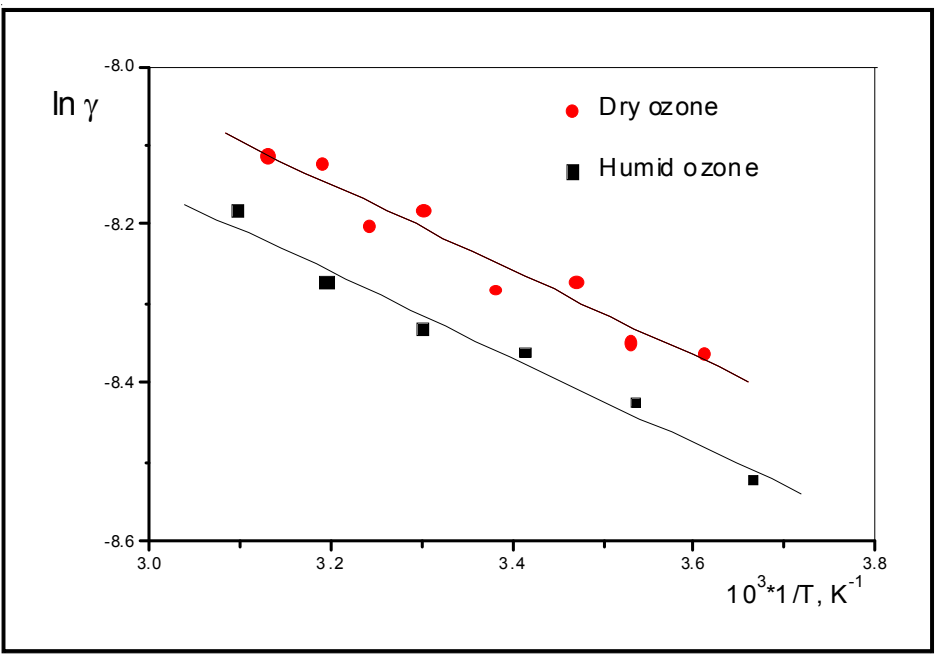

Fig. 4. Temperature dependence of catalytic activity at dry and humid conditions, temperature range $273-323 \mathrm{~K}$, ozone flow rate $81 \mathrm{~h}^{-1}$ 


\section{ТЕХНИКО-ТЕХНОЛОГИЧЕСКИЕ ИННОВАЦИИ}

decomposition depends on temperature, but at $258 \mathrm{~K}$ the steady state of the curve is reached faster. The obtained values of $\gamma$ are close to the coefficients reported in literature [15]. Therefore, it could be concluded that at low values of gas flow rate, a reason for the dependence of the catalytic activity from gas flow rate is the influence of the external diffusion over the kinetics of the process of heterogeneous catalytic ozone decomposition on catalyst surface, i.e. the process takes place mainly in the outer diffusion region or in the transition diffusion-kinetic region.

Fig. 6 shows the dependence of $\gamma$ on gas flow humidity at $298 \mathrm{~K}$. The values of $\gamma$ decrease with increasing the humidity, but nevertheless these values remain relatively high. The effect of water vapor may be result of thin film formation on the catalytic surface that makes the diffusion of ozone to catalytic centers more difficult. The humidity of $\mathrm{O}_{3} / \mathrm{O}_{2}$ gas flow was measured to be $50 \%$.

A popular technique used to characterize manganese oxide containing catalyst and to determine the identity of the manganese oxide phase at high loadings $(>6 \%)$ has been $\mathrm{X}$-ray diffraction (XRD) [2; 13]. The X-ray diffraction results for the cement-containing metal oxide catalyst are presented on Fig. 7. The diffractogram for the catalyst sample showed peaks with a certain number of large intensities at different $2 \theta$ values. The peaks at $39^{\circ}$ and $35.5^{\circ}$ correspond to copper oxide $(\mathrm{CuO})$. The diffraction features for the catalyst at $33^{\circ}$ and $55.1^{\circ}$ are indicative of bixbyite-o

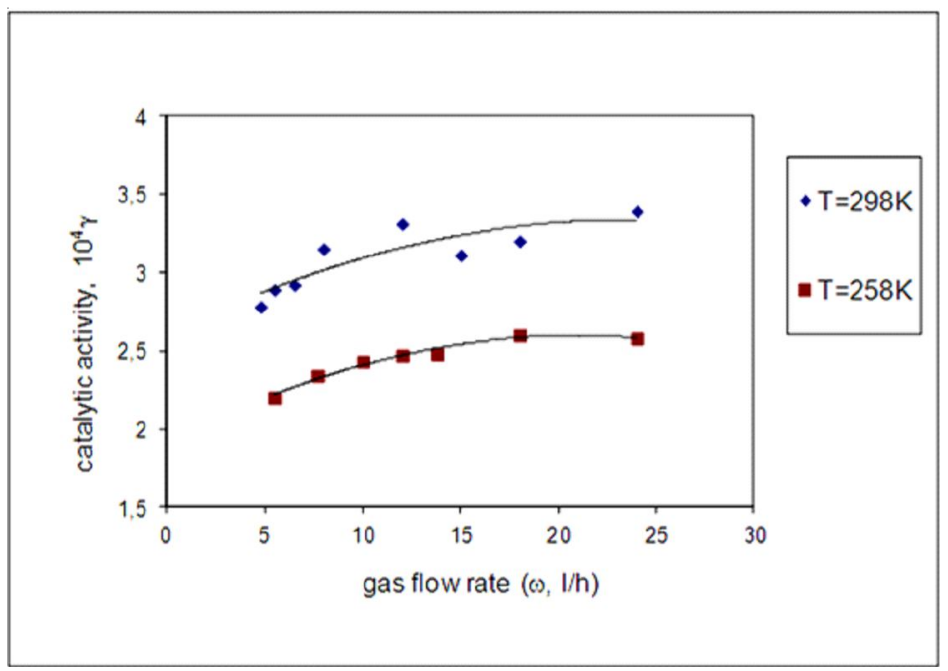

Fig. 5. Flow rate dependence of catalytic activity at 258 and $298 \mathrm{~K}$, ozone flow rate range $5-251 \mathrm{~h}^{-1}$

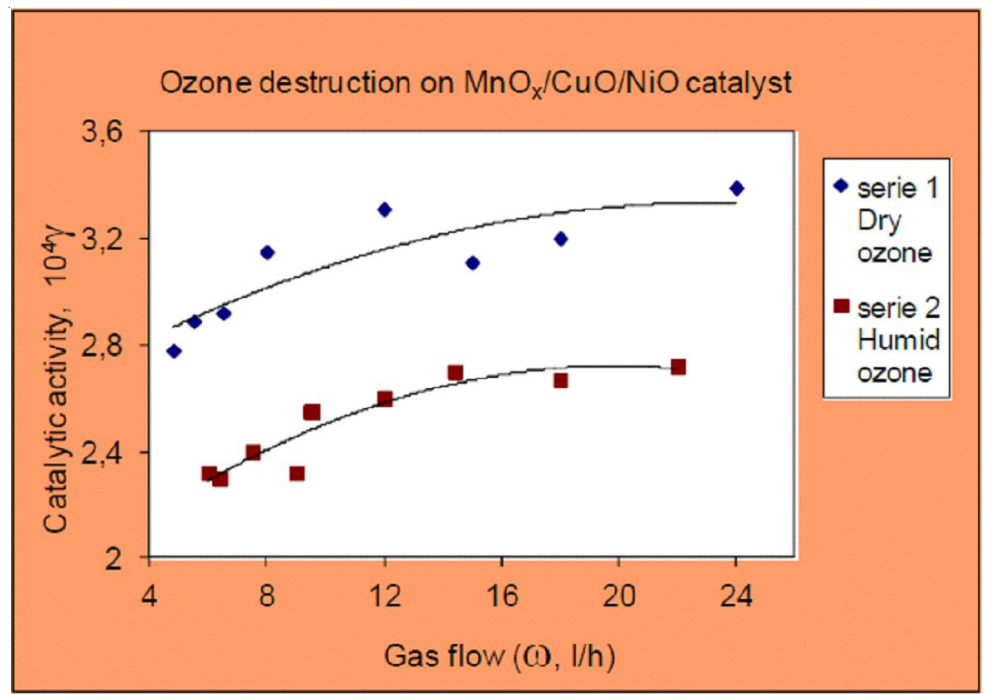

Fig. 6. Flow rate dependence of catalytic activity at dry and humid conditions, ozone flow rate range $4-261 \mathrm{~h}^{-1}$ 


\section{ТЕХНИКО-ТЕХНОЛОГИЧЕСКИЕ ИННОВАЦИИ}

$\left(\mathrm{Mn}_{2} \mathrm{O}_{3}\right)$. The metal oxide catalyst sample peaks at $43^{\circ}, 37.2^{\circ}$ and $62.9^{\circ}$ are due to nickel oxide (NiO). The catalyst diffraction peaks at $36.1^{\circ}$, $32.4^{\circ}$ and $59.9^{\circ}$ correspond to hausmannite $\left(\mathrm{Mn}_{3} \mathrm{O}_{4}\right)$. Finally, the cement diffraction peaks at $20^{\circ}, 25.5^{\circ}$ and $29.5^{\circ}, 47.5^{\circ}$ are due respectively to grossite $\left(\mathrm{CaAl}_{4} \mathrm{O}_{7}\right)$ and calcite $\left(\mathrm{CaCO}_{3}\right)$. In conclusion, the information which can be deduced from the X-ray diffractogram for this catalyst is that there are three metal oxides as the manganese oxide is present in two forms $-\mathrm{Mn}_{2} \mathrm{O}_{3}$ and $\mathrm{Mn}_{3} \mathrm{O}_{4}$.
It could also be seen that the cement support of the catalyst is build mainly by two components $\mathrm{CaAl}_{4} \mathrm{O}_{7}$ and $\mathrm{CaCO}_{3}$.

The TPR experiment was carried out for the supported on cement metal oxide catalyst (Fig. 8). The $\mathrm{H}_{2}$ consumption was monitored by thermal conductivity detector in the course of time. Manganese-containing catalyst was already studied using TPR [8]. The peak temperatures of reduction on Fig. 8 are $527 \mathrm{~K}$, $596 \mathrm{~K}, 643 \mathrm{~K}$ and $976 \mathrm{~K}$ or the reduction

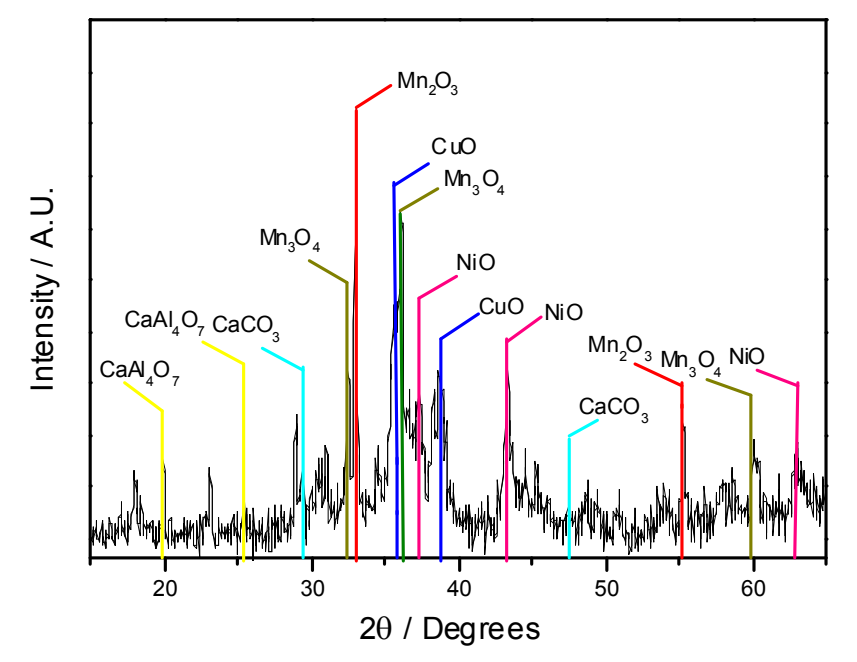

Fig. 7. $\mathrm{XRD}$ of $\mathrm{MnO}_{\mathrm{x}} / \mathrm{CuO} / \mathrm{NiO}$ catalyst supported on cement

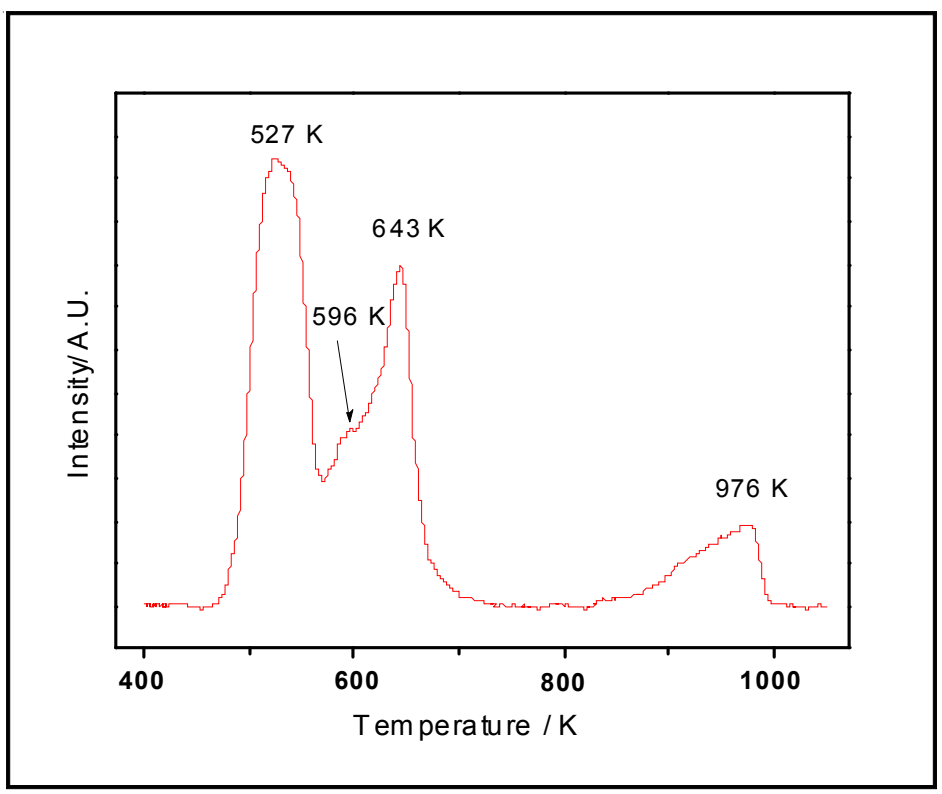

Fig. 8. TPR of $\mathrm{MnO}_{\mathrm{x}} / \mathrm{CuO} / \mathrm{NiO}$ catalyst supported on cement 


\section{ТЕХНИКО-ТЕХНОЛОГИЧЕСКИЕ ИННОВАЦИИ}

temperature of the catalyst was in the range 527$976 \mathrm{~K}$. The bulk reduction peaks at $596 \mathrm{~K}$ and $643 \mathrm{~K}$ can be identified for the manganese oxide in the cement-containing metal oxide mixture while the peak at $976 \mathrm{~K}$ can be related with reduction of the nickel oxide $[3 ; 8]$.

The most possible mechanism $[10 ; 12]$ of catalytic ozone decomposition can be presented as follows:

$$
\begin{gathered}
\mathrm{O}_{3}+* \rightarrow \mathrm{O}_{2}+\mathrm{O}^{*}, \\
\mathrm{O}_{3}+\mathrm{O}^{*} \rightarrow \mathrm{O}_{2}^{*}+\mathrm{O}_{2}, \\
\mathrm{O}_{2} \rightarrow \mathrm{O}_{2}+*,
\end{gathered}
$$

where the symbol * was used to denote surface sites. In step (1) ozone decays and the finding that the adsorbed ozone does not desorbs ascertains the irreversibility of steps (1) and (2). Further peroxide particles are formed in accordance with step (2) and then oxygen is desorbed from the catalytic surface - step (3). The finding that the peroxide species could not be formed from molecular oxygen at any conditions shows the irreversibility of step (3).

The FT-IR spectra of the catalyst before and after ozone decomposition are shown in Fig. 9. The two similar spectra indicate that the catalyst does not change practically during the reaction. A broad band at $3415-3425 \mathrm{~cm}^{-1}$ and also the band at $1410-1430 \mathrm{~cm}^{-1}$ are associated with the vibrations of water molecules [6;25]. The intensive bands at $515-530 \mathrm{~cm}^{-1}$ in accordance with literature [1], were assigned to the stretching vibration of the surface metaloxygen bond.

The FT-IR spectra of cement-oxide catalyst after dry ozone decomposition $(a)$ and after humid ozone decomposition $(b)$ are presented in Fig. 10. The spectra are almost identical, showing that the catalyst structure is not altered during the humid catalytic reaction. The broad adsorption band at $3430 \mathrm{~cm}^{-1}$ appears from the stretching vibration of hydrogen bonded hydroxyl groups [25]. The adsorption band at $1635 \mathrm{~cm}^{-1}$ is due to vibrations of water molecules [24]. The intensive band at 520$530 \mathrm{~cm}^{-1}$ appears at higher manganese concentrations and, in accordance with literature, can be attributed to well-defined $\mathrm{Mn}_{2} \mathrm{O}_{3}$ phase [2].

\section{Conclusions}

1. The catalyst based on $\mathrm{MnO}_{\mathrm{x}} / \mathrm{CuO} / \mathrm{NiO}$ has high efficiency in the reaction of ozone decomposition both at dry and wet conditions.

2 . The catalyst work is stable and its activity does not change dramatically by varying temperature, $\mathrm{O}_{3} / \mathrm{O}_{2}$ flow rate and humidity.

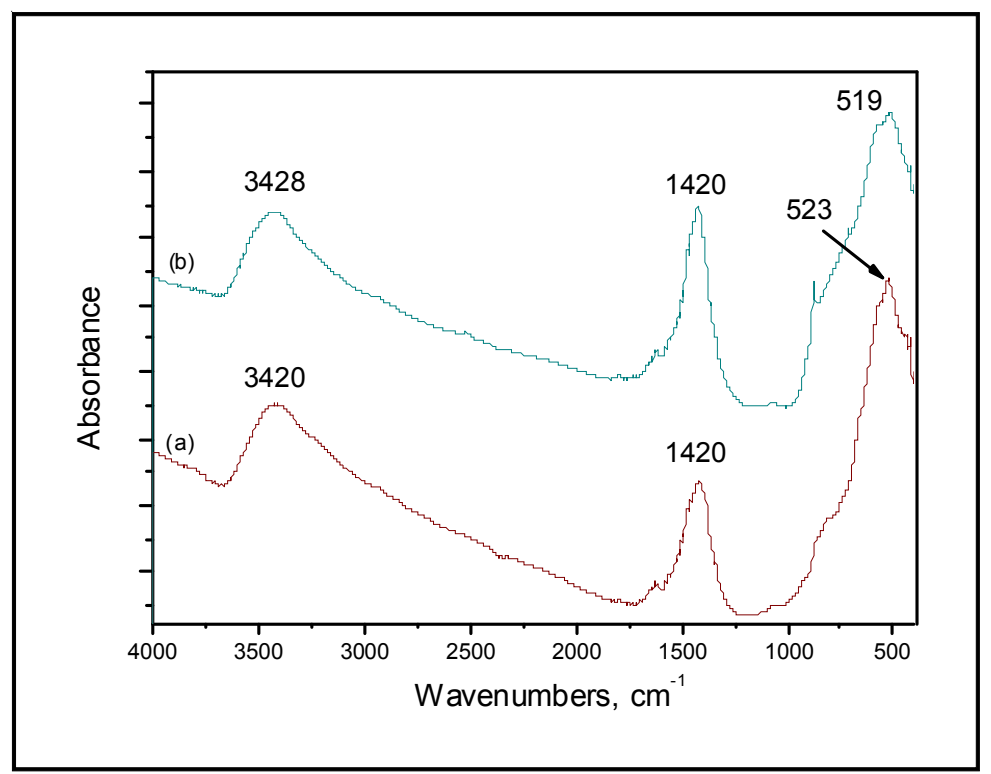

Fig. 9. FT-IR spectra of $\mathrm{MnO}_{\mathrm{x}} / \mathrm{CuO} / \mathrm{NiO}$ catalytic samples obtained before ozone decomposition $(a)$ and after ozone decomposition for $8 \mathrm{~h}(b)$ 


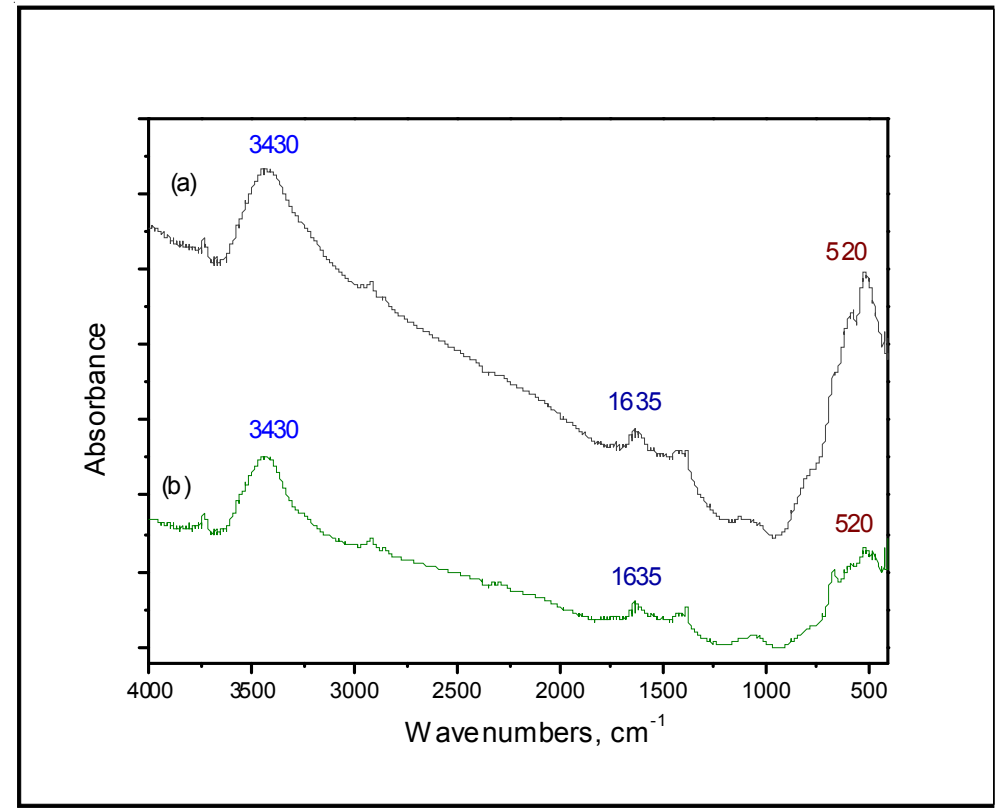

Fig. 10. FT-IR spectra of cement-oxide catalyst after dry ozone decomposition $(a)$ and after humid ozone decomposition $(b)$

3. XRD analysis has proven to be a useful tool for the identification of all metal oxide phases in catalyst mixture. The temperature programmed reduction of the catalyst denotes its high reducibility.

4. The FT-IR spectral band at $526 \mathrm{~cm}^{-1}$ shows that the catalyst stays unchangeable during the ozone decomposition for about $8 \mathrm{~h}$.

5. The FT-IR spectra after humid ozone decomposition indicates that even decomposing ozone in humid conditions the catalyst structure does not change practically during the reaction.

\section{REFERENCES}

1. Bielanski A., Haber J. Oxygen in Catalysis. Marcel Dekker Inc., New York, 1991.

2. Buciuman F., Patcas F., Craciun R., Zhan D.R.T. Vibrational Spectroscopy of Bulk and Supported Manganese Oxides. Phys. Chem., 1998, no. 1, p. 185.

3. Dhandapani B., Oyama S.T. Gas Phase Ozone Decomposition Catalysts. J. Appl. Catal. B: Environmental, 1997, no. 11, p. 129.

4. Einaga H., Futamura S. Comparative Study on the Catalytic Activities of Alumina-Supported Metal Oxides for Oxidation of Benzene and Cyclohexane With Ozone. React. Kinet. Catal. Lett., 2004, no. 81, p. 121.

5. Frank-Kamenetskii D.A. Diffusion and Heat Transfer in Chemical Kinetics. Moscow, 1987. (in Russian).
6. Gomez-Serrano V., Alvarez P. M., Jaramillo J., Beltran F.J. Formation of Oxygen Structures byOzonation of Carbonaceous Materials Prepared from Cherry Stones-II, Kinetic Study. Carbon, 2002, no. 40, p. 513.

7. Heisig C., Zhang W., Oyama S.T. Decomposition of Ozone Using Carbon Supported Metal Oxide Catalysts. Appl. Catal. B: Environ., 1997, no. 14, p. 117.

8. Kapteijn F., Van Langeveld A.D., Moulijn J.A., Andreini A., Vuurman M.A., Turek M.A., Jehng J.M., Wachs I.E. Alumina-Supported Manganese Oxide Catalysts. J. Catal., 1994, vol. 150, p. 94.

9. Konova P., Stoyanova M., Naydenov A., Christoskova St., Mehandjiev D. Catalytic oxidation of VOCs and $\mathrm{CO}$ by ozone over alumina supported cobalt oxide. J. Appl. Catal. A: Gen., 2006, vol. 298, p. 109.

10. Li W., Gibbs G.V., Oyama S.T. Mechanism of Ozone Decomposition on Manganese Oxide: 1. In Situ Laser Raman Spectroscopy and ab Initio Molecular Orbital Calculations. J. Am. Chem. Soc., 1998, vol. 120, p. 9041.

11. Li W., Oyama S. T. Absolute Determination of Reaction Mechanisms by in Situ Measurements of Reaction Intermediates. Top. Catal., 1999, vol. 8, p. 75.

12. Li W., Oyama S.T. The Mechanism of Ozone Decomposition on Manganese Oxide: 2. Steady-state and Transient Kinetic Studies. J. Am. Chem. Soc., 1998, vol. 120, p. 9047.

13. Lo Jacono M., Schiavello M. The Influence of Preparation Methods on Structural and Catalytic Properties of Transition Metal Ions Supported on Alumina. Delmon B., Jacobs P., Poncelet G., eds. Preparation of Catalysts. New York, 1976, p. 473. 
14. Lunin V.V., Popovich M.P., Tkachenko S.N. Physical Chemistry of Ozone. Moscow, Moscow University Publ. House, 1998, pp. 377-444. (in Russian).

15. Martinov I.V., Tkachenko S.N., Demidyuk V.I., Egorova G.V., Lunin V.V. Addition Influence Over Cement-Containing Catalysts Activity in Ozone Decomposition. J. of Moscow Univ., Ser. 2, Chemistry, 1999, vol. 40, p. 355. (in Russian).

16. Oyama S.T. Chemical and Catalytic Properties of Ozone. Catal. Rev. Sci. Eng., 2000, vol. 42, p. 279.

17. PerryR.H., Green D. Perry's Chemical Engineer's Handbook. NewYork, MoGraw-Hill, 1989, pp. 3-147.

18. Radhakrishnan R., Oyama S.T., Chen J., Asakura A. Electron Transfer Effects in Ozone Decomposition on Supported Manganese Oxide. J. Phys. Chem. B, 2001, vol. 105 (19), p. 4245.

19. Radhakrishnan R., Oyama S.T., Ohminami Y., Asakura K. Structure of $\mathrm{MnO}_{x} / \mathrm{Al}_{2} \mathrm{O}_{3}$ Catalyst: A Study Using EXAFS, In Situ Laser Raman Spectroscopy and Ab Initio Calculations. J. Phys. Chem., 2001, vol. 105, p. 9067.

20. Rakitskaya T.L., Bandurko A.Yu., Ennan A.A., Paina V.Ya., Rakitskiy A.S. Carbon-Fibrous-MaterialSupported Base Catalysts of Ozone Decomposition. Micro. Meso. Mater., 2001, vol. 43, p. 153.

21. Rakovsky S., Zaikov G. Kinetics and Mechanism of Ozone Reactions with Organic and Polymeric Compounds in Liquid Phase. $2^{\text {nd }}$ ed. New York, Nova Science Publishers Inc., 2007, pp. 1-340.
22. Semenova L.M., Bakhracheva Yu.S., Semenov S.V. Laws of Formation of Diffusion Layers and Solution of the Diffusion Problem in TemperatureCycle Carbonitriding of Steel. Metal Science and Heat Treatment, 2013, vol. 55, no. 1-2, pp. 34-37.

23. Shapochkin V.I., Semenova L.M., Bakhracheva Yu.S., Gyulikhandanov E.L., Semenov S.V. Effect of Nitrogen Content on the Structure and Properties of Nitrocarburized Steel. Metal Science and Heat Treatment, 2011, vol. 52, no. 9-10, pp. 413-419.

24. Stoyanova M., Konova P., Nikolov P., Naydenov A., Christoskova S., Mehandjiev D. Alumina-Supported Nickel Oxide for Ozone Decomposition and Catalytic Ozonation of $\mathrm{CO}$ and VOCs. Chem. Eng. Journal, 2006, vol. 122, p. 41.

25. Subrahmanyam C., Bulushev D., KiwiMinsker L. Dynamic Behaviour of Activated Carbon Catalysts During Ozone Decomposition at Room Temperature. J. Appl. Catal. B: Environmental, 2005, vol. 61, p. 98.

26. Tong S., Liu W., Leng W., Zhang Q. Characteristics of $\mathrm{MnO}_{2}$ Catalytic Ozonation of Sulfosalicylic Acid Propionic Acid in Water. Chemosphere, 2003, vol. 50, p. 1359.

27. Zavadskii A.V., Kireev S.G., Muhin V.M., Tkachenko S.N., Chebkin V.V., Klushin V.N., Teplyakov D.E. Thermal Treatment Influence Over Hopcalite Activity in Ozone Decomposition. J. of Phys. Chem., 2002, vol. 76, p. 2278. (in Russian).

\section{РАЗЛОЖЕНИЕ ОЗОНА НА ПОВЕРХНОСТИ КАТАЛИЗАТОРА ОКСИДА МЕТАЛЛА}

\section{Батаклиев Тодор Тодоров}

Доцент, кандидат химических наук,

Институт катализа Болгарской академии наук

todor@ic.bas.bg

ул. акад. Г. Бончев, корп. 11, 1113 София, Болгария

\section{Георгиев Владимир Фердинандов}

Доцент, кандидат химических наук,

Институт катализа Болгарской академии наук

vlado@ic.bas.bg

ул. акад. Г. Бончев, корп. 11, 1113 София, Болгария

\section{Анашков Мефодий Пырванов}

Доцент, кандидат химических наук,

Институт катализа Болгарской академии наук

anachkov@ic.bas.bg

ул. акад. Г. Бончев, корп. 11, 1113 София, Болгария 


\section{Раковский Славико Кирилов}

Профессор, доктор химических наук,

Институт катализа Болгарской академии наук

rakovsky@ic.bas.bg

ул. акад. Г. Бончев, корп. 11, 1113 София, Болгария

\section{Заиков Геннадий Ефремович}

Доктор химических наук, профессор,

руководитель отдела биологической и химической физики полимеров,

Институт биохимической физики им. Н. М. Эмануэля РАН

chembio@sky.chph.ras.ru

ул. Косыгина, 4, 119334 г. Москва, Российская Федерация

Аннотация. В настоящей работебыл исследован механизм каталитического разложения озона на молекулярный кислород из каталитической смеси, содержащей марганец, медь и никель оксиды. Реакция была изучена в присутствии термически модифицированных каталитических образцов, работающих при различных температурах и расходах озона. Фазовый состав металла оксидного катализатора определялся методом рентгеновской дифракции. Катализатор смеси показал высокую активность разложения озона на мокрой и сухой $\mathrm{O}_{3} / \mathrm{O}_{2}$ смеси газов. Был предложен механизм каталитической деградации озона.

Ключевые слова: озон, катализатор, разложение, синтез, кинетика, механизм. 